\title{
Reflection Article
}

\section{Reflections on psychosocial care in the field of children and adolescents mental health}

\author{
Reflexôes sobre a atençâo psicossocial no campo da saúde mental \\ infantojuvenil
}

\author{
Amanda Dourado Souza Akahosi Fernandes ${ }^{a}$ (D), Thelma Simóes Matsukura ${ }^{a}$ (D), \\ Isabela Aparecida de Oliveira Lussia ${ }^{a}$ (D), Sabrina Helena Ferigato ${ }^{a}$ (D), Giovana Garcia Morato ${ }^{a}$ \\ aUniversidade Federal de São Carlos - UFSCar, São Carlos, SP, Brasil
}

How to cite: Fernandes, A. D. S. A., Matsukura, T. S., Lussi, I. A. O., Ferigato, S. H., \& Morato, G. G. (2020). Reflections on psychosocial care in the field of children and adolescents mental health. Cadernos Brasileiros de Terapia Ocupacional. 28(2), 725-740. https://doi.org/10.4322/2526-8910.ctoARF1870

\begin{abstract}
$\underline{\text { Abstract }}$
The objective of this study was to discuss and reflect on Psychosocial Care for children and adolescents, as well as to point out the impasses and the main challenges in this field today. This is a reflexive essay, based on the analysis of institutional documents and notes from the scientific literature that support the theoretical contribution of Psychosocial Care and the historical path of transformations in child and adolescent mental health care in Brazil. It was possible to elucidate aspects related to the field of psychosocial care in general and child and adolescent mental health in particular, and to discuss them in order to advance in the debates regarding the supply and structure of care in the Sistema Único de Sauide. It could be possible to construct critical analyzes, producing theoretical subsidies for later studies, besides enabling the strengthening of this field for the children and adolescents.
\end{abstract}

Keywords: Health policy, Mental health, Child, Adolescence.

\section{$\underline{\text { Resumo }}$}

O objetivo deste estudo foi discorrer e refletir sobre a Atenção Psicossocial para a infância e adolescência, bem como apontar os impasses e os principais desafios presentes neste campo na atualidade. Trata-se de um ensaio reflexivo, apresentado com base na análise de documentos institucionais e apontamentos da literatura científica que sustentam o aporte teórico da Atenção Psicossocial e o percurso histórico das transformaçôes na assistência à saúde mental infantojuvenil no Brasil. Foi possível elucidar aspectos concernentes ao campo da atenção psicossocial, em geral, e da saúde mental infantojuvenil, em específico, e discuti-los com vistas a avançar nos debates que dizem respeito à oferta e à estrutura de cuidado no Sistema Único de Saúde. Considera-se que 
análises críticas possam ser construídas, produzindo subsídios teóricos para estudos posteriores, além de viabilizar a afirmação do fortalecimento desse campo para a população infantojuvenil.

Palavras-chave: Política de Saúde, Saúde Mental, Criança, Adolescência.

\section{Introduction}

The historical path of child and adolescent mental health care constitution in Brazil shows that it is quite unique and late, when compared to the same service for adults, so that the specific public policies aimed at this segment were built and proposed mainly in recent years (Taño \& Matsukura, 2015). In this sense, taking as a starting point this historical path, as well as the social, political, economic and ideological determinants that have framed and have been outlining a model of assistance for this population, it is essential to elucidate and reflect on how Psychosocial Care for children and adolescent is currently constituted and configured in Brazil, as well as its impasses and challenges.

Before we begin, however, here is an important observation regarding recent changes in the scope of Public Mental Health Policies in Brazil which have been implemented through guidelines and regulations contained in Resolution No. 32 of December 14, 2017, and the Ordinance No. 3588 of December 21, 2017, even without the approval of SUS formal social control bodies. There is, for example, the change in the structure of the Rede de Atenção Psicossocial (RAPS), which excludes strategies and actions related to psychosocial rehabilitation centers (generation of work and income, solidarity enterprises and social cooperatives) and also, the inclusion of psychiatric hospitals as a point of care service (Brasil, 2017).

Although it is possible to measure the negative impacts and threats that such measures mean to care practices and the entire care model in force since the early 2000s - the field of Psychosocial Care - we warn that such measures will not be addressed in this essay, since the reflexive analysis presented here does not reach the facts that occurred so recently. Nevertheless, our position here is sharing the concern and willingness to cope with the guarantee of what we have invested and developed in the field of Brazilian mental health.

Thus, we consider that reflecting on the mental health care of children and adolescents based on their paradigms and its socio-historical determinants is a necessary investment not only for the particularities and specificities presented by the population of children and adolescents, who request a singular look at their needs and care strategies, but also because the history of this segment care has been built, for a long time, distant from the whole critical process to the hegemonic psychiatric model in the field of mental health in Brazil.

It is noteworthy that there is a gap between the constitution paths of mental health care for adults and for childhood and adolescence that certainly imposes an investigation and critical reflection on what the encounter between these stories produced (or has been producing) in the theoretical-practical constructions of the Psychiatric Reform, especially when children and adolescents are incorporated 
into the mental health public policy agenda and, therefore, begin to have strategies, programs, funding and organized arrangements for their care, induced by State policies.

This essay aims at discussing and reflecting on Psychosocial Care, with emphasis on childhood and adolescence, as well as to point out the impasses and challenges of this field. To this end, this essay was based on reflection and analysis of institutional documents and the national literature that support the field of Psychosocial Care and on the path of transformations and care in children and adolescent mental in Brazil. Institutional documents, laws, regulations and programs established for the purpose of implementing health policies were accessed in electronic version, on ministerial electronic sites.

We seek to evidence, even from a flyover, the basic concepts that support the practices and subsequently reflect on the historical-political panorama of child and adolescent mental health care, thus offering elements for a discussion to understand the constitution of the psychosocial paradigm in the field of childhood and adolescence.

\section{Locating and Conceptualizing Psychosocial Care}

The horizon of mental health field and its policies, which have been constructed since the mid-1980s, is a profound transformation of what is called care, conceived as a set of care and assistance strategies for the population in psychological distress (Yasui \& Costa-Rosa, 2008). Psychosocial Care has its origin in the theoretical and practical subsidies of several international historical experiences, such as French Sector Psychiatry, American Community Psychiatry, Antipsychiatry, Institutional Psychotherapy and especially Italian Democratic Psychiatry (Costa-Rosa et al., 2003). In addition, in the national context, the production of mental health as a public policy received significant contributions from Saude Coletiva. These contributions were (re)constructed and singularized in the encounter with the dimension of Brazilian practical experiences, coming especially from the processes of deinstitutionalization and construction of Centros de Atenção Psicossocial (CAPS)/ Núcleos de Atenção Psicossocial (NAPS) and other substitute equipment (Costa-Rosa et al., 2003).

It is important to emphasize that the theoretical contributions underlying these experiences go over, mainly, concepts of Sociology and Psychology in an expanded way, and those concerning more specific aspects of the Philosophy of Difference, Psychoanalysis and Historical Materialism (Costa-Rosa et al., 2003). In this sense, the concept of Psychosocial Care was and has been nourished by diverse epistemological bases and practices that ended up in the construction of Brazilian social policies in the field of mental health.

In this pot of knowledge and experiences, influences and investments, Psychosocial Care has been constituted, currently established in the country as the term that designates the public mental health policy of the Ministry of Health, delimiting, in recent decades, "[...] a field of knowledge and practices crossed by an ethical-political ideology that replaces hospital and medical-centered psychiatry, ideologically subordinated, but still dominant in everyday practices" (Costa-Rosa, 2013, p. 9). 
The scope of this dimension and status of Psychosocial Care is also based, in Brazil, on the fundamental theoretical systematization undertaken by Costa-Rosa (2000), which sought, based on considerations about mental health practices in two spheres - political-ideological and theoretical-technical - to present some parameters that would make it possible to elucidate Psychosocial Care as an emerging paradigm in opposition to the Asylum-type paradigm. In this direction, the four main parameters are presented as:

1) Ways of conceiving the "object" and working instruments - which concern the way in which health-disease-cure trinomial is understood, as well as the instruments used in interventions;

2) Characteristics of the institution's organization - refers to the forms of intrainstitutional relations and, consequently, to the different ways of managing powers;

3) Characteristics of the types of relationships established with the population served refer to the different possibilities of exchange between the individual and care equipment;

4) Characteristics of the results produced by the interventions undertaken with regard to therapy and ethics - brings together the political and sociocultural purposes arising from the practice performed.

With this structure, and through the alignment of pairs of opposites between the modes of practices (Asylum Mode $x$ Psychosocial Mode), the author sought to evidence and sustain the Psychosocial Mode as an emerging paradigm to be affirmed in the field of mental health (Costa-Rosa, 2000).

They defend that, as opposed to the asylum mode - paradigm of the practices that were prevalent up to that moment - the psychosocial mode was designated as a paradigm structured based on the practices disseminated by the Psychiatric Reform (Costa-Rosa, 2000).

Thus, it is verified that the current structure of the Psychosocial Care field was also being nourished by theorizations and reflexive exercises that, added to international historical events and experiences of national care transformation, as already mentioned, allowed us to assume Psychosocial Care as "[...] a set of knowledge and practices organized in a persistent and consistent way, by an ethical-political discourse [...]" (Costa-Rosa, 2013, p. 20), which modifies not only the way the assistance is given in health but also transforms the way civil society relates to the follies it produces and to people in psychological distress.

It is argued, based on what has been exposed so far and justified, especially, by the constitution path of Psychosocial Care in Brazil that it is currently the structuring arrangement of RAPS, theoretically and methodologically supporting the work and care process that guides its functioning, as well as the design and orientation of its devices and practices. 


\section{Historical Path of Transformations in Children and Adolescents Mental Health Care in Brazil}

The care for children and adolescents, with regard to mental health, remained for a long time on the sidelines, when compared to the scenario of adults with psychological distress. Until the 19th century, those children and adolescents who presented socially unaccepted behaviors were considered crazy and, therefore, should be prisoners in psychiatric hospitals, sharing the same spaces as adults (Reis et al., 2010). Although this is not the induced policy, the practice still exists in some places in Brazil.

According to Reis et al. (2010), in the international scenario two main currents supported the theoretical bases of child and adolescent psychopathology, the first being called adultmorphism (the same understanding of adult psychopathology was taken for childhood and adolescence) and the second that included children in the list of intellectual disabilities and adolescents in the category of "offenders". Thus, care was supported by private, philanthropic and welfare institutions, without State accountability.

So we observed that, in addition to psychiatric hospitals, similar modes of exclusion and violence were present for children and adolescents, and for many decades they were the solution to social problems resulting also from the lack of a care policy for this population (Couto, 2001; Couto et al., 2008; Ribeiro, 2006).

This scenario remained for many decades in Brazil and only from important events - such as the Sanitary Reform, the Psychiatric Reform, the 1988 Constitution and the recognition of the child as a subject of rights, through the Estatuto da Criança e do Adolescente (ECA), the transformations began, through actions induced by the State and organized social movements (Reis et al., 2010; Brasil, 2005; Amstalden et al., 2010).

Moreover, after these milestones, other factors contributed to reform the care model for children and adolescents, even without reaching them at first. Among them, we point out the construction of social movements, such as the Mental Health Workers' Movement, the Anti-Mental Hospital Movement, the approval of Law No. 10216, the Caracas Declaration and the National Mental Health Conferences (Amarante, 1995; Schechtman \& Alves, 2014). In this course, substitute services for adults were implemented, aiming creating an integrated network of mental health care, supported by territorial and community care services (Brasil, 2005; Amstalden et al., 2010).

With regard to childhood and adolescence, it was only from the year 2000 that the first CAPS for children and adolescents (CAPSij) appeared and, in the political field, only in 2004 the Ministry of Health instituted the Fórum de Saúde Mental Infantojuvenil, supported by government and non-governmental policies, aiming to build, collectively and across sectors, the bases, principles and guidelines of a Public Mental Health Policy addressed to this population (Brasil, 2012, 2014a).

We verified here that the construction of a theoretical-technical-institutional apparatus for the care of children and adolescents arises at a time when such structuring was already taking place within the scope of adult care, that is, at that moment the stories met, so that the experience of the Psychiatric Reform movement 
and its consequences in the Brazilian context becomes a contribution and support for the construction of a mental health care field for children and adolescents.

We consider the creation of CAPSij as the first action of the State to address mental health issues of children and adolescents an official response of SUS to the care need of this population that did not find its place in the Psychosocial Care field (Couto \& Delgado, 2015).

Following the movements of the time, in 2005, the Ministry of Health adopts a booklet whose title evidenced the attempt of a specific political direction for the field of mental health of children and adolescents. The document entitled "Pathways to a mental health policy for children and adolescents" highlights the forum as an important political articulator for childhood and adolescence and addresses the principles of care for this population, emphasizing the understanding that children and adolescents are subjects of rights; universal reception; implied referral; permanent construction of the network; and importance of the territory and intersectoriality. In addition, this document considers that in order to promote the development of children and adolescents, and to enable them reaching their potential, the society, through State actions, needs to ensure mechanisms of education, social protection, inclusion, promotion and guarantee of the rights of children, adolescents and families (Brasil, 2005).

However, studies indicate that the care provided in the field of mental health of children and adolescents for those in a situation of intense suffering is still quite quantitative and qualitatively out dated and, although the CAPSij are the places of priority care for those subjects, there are weaknesses in the guarantee of care, which directly derives in the lack of comprehensive and effective care (Taño \& Matsukura, 2015).

In this direction, the study by Fernandes \& Matsukura (2015) identified that, although CAPSij is a device that advocates actions that go beyond the walls of the institution and reach the territory, most of the care proposals still occur internally, in ambulatory formats. We think, however, that the prevalence of intramural actions does not occur due to operation ideology of the service, but mainly because difficulties in structure, training and human resources difficulties that prevent efforts to overcome strictly internal and intersectoral actions and advance, expanding them to other social contexts.

In the search to enable conditions for mental health advancing, in 2011, the Ministry of Health instituted, through Ordinance No. 3088, the Rede de Atenção Psicossocial (RAPS), whose purpose was the creation, expansion and articulation of health care centers for people in psychological distress and with needs arising from the use of alcohol and other drugs within the scope of the Sistema Unico de Saude (SUS), recommending health care to the most vulnerable groups, including children and adolescents (Brasil, 2011).

Specifically, the Fórum de Saude Mental Infantojuvenil, published in 2014 a document compiling the productions in the area from 2005 to 2011, reaffirming what was already under construction, but also incorporating new recommendations. For example, the document pointed out "The Challenges for the Field of Childhood and Youth within RAPS". The discussion focused on the need to qualify the debate on RAPS and their assistance centers, as well as to formulate ways to expand the access of children, adolescents and young people to them. The propositions presented aimed at 
strengthening and determination of Primary Care in child and adolescent mental health care; to stimulate and strengthen intersectoral actions and to bring it closer to Education (Brasil, 2014a).

In line with the Forum, in the same year 2014, the Ministry of Health prepared another document entitled "Psychosocial Care to children and adolescents in the SUS: weaving networks to ensure care". This document points to the construction of mental health care for children and adolescents based on some guidelines, reaffirming and expanding the same principles pointed out in 2005 by the Ministry of Health. In addition, it highlights a number of aspects specific to this population, such as the guarantee of health as a fundamental right, the constitution of RAPS, the role of education, the problem of the use of alcohol and other drugs, integral social protection, among others (Brasil, 2014b).

Thus, when considering the processes of transformation of the mental health care model for childhood and adolescence, it is essential to know, evaluate and describe how the theoretical-practical transformations have been effected, aligning the practice with a critical reflection (Taño \& Matsukura, 2015; Cunha \& Boarini, 2001). Furthermore, we need to recognize that, in such complexity and challenges in the field of mental health of children and adolescents, greater investments will be demanded, for sure, in different spheres of SUS management aiming at the construction of a Psychosocial Care model to children and adolescents in psychological distress (Couto \& Delgado, 2015).

\section{Challenges of Constructing a Field of Psychosocial Care for Children and Adolescents}

As explained in the previous section, the proposals for mental health policies that currently govern care for childhood and adolescence start from an institutional model based on the principles and guidelines of SUS, operationalized mainly, through RAPS. In this direction, we understand that, within this perspective of network care, equipment and professionals assume the social function of care. Therefore, in addition to being centers of assistance, RAPS advocate dimensions that concern access, bonding and articulation of assistance centers.

Although this scenario, which brings together conceptions, organization and care practices, integrates dimensions of the so-called Psychosocial Care, it is essential to understand, as Yasui (2009) points out, that this cannot be conceived as a mere modification of the mental health services, translated into changes in the institutional organization for care management or work processes, but it rather needs to be done, specifically, through the construction of spaces that produce social relations, which are based on principles and values that have as their horizon the social transformation and, consequently, the construction of social spaces for people in psychological distress.

It is important to emphasize that, although the aforementioned author defends the principles, values and dimensions that should be incorporated into the practice of Psychosocial Care, it is necessary to problematize and reflect on which way $R A P S$ is configured and operationalized effectively in the daily practice of children and adolescents care. This discussion is justified when the historical course of the 
RAPS constitution is rescued, because, although it was thought and structured considering the demands of the different vulnerable groups, the hypothesis is that the parameters for its constitution descended, mostly or even entirely, from what was intended as a model and philosophy of mental health care for adults, precisely because of the historical path of care transformation and because the structure existed only for this segment, in fact.

For example, the CAPS directed to adults is intended for the population with severe and persistent mental disorder; thus, their organization and care service should be guided by these characteristics presented by the assisted population. However, we question whether, when designing this structure and conception of CAPS for the child and adolescent, some risks are not induced, such as: 1) By assuming severe and persistent mental disorder as a "criterion" that guides the evaluation of cases that will be monitored or not in the service, there is a risk of neglecting an experience of psychic suffering, its dimension and impacts at this stage of life; 2) Not accepting what is presented as less serious (which may turn out to be potentially serious) and/or, as is often the case, welcoming all kinds of suffering without the structure and support that this reality demands (Beltrame $\&$ Boarini, 2013). Thus, it is possible that, even though in thesis the structure of the CAPS for childhood and adolescence is adequate, the joint implementation of other equipment and/or care strategies to CAPSij would give greater contribution and support for care based on psychosocial assistance.

We recognize, and studies in the area have also shown, the absolute relevance of CAPSij and the actions that have been courageously developed there and their fundamental role for this population care. Nevertheless, at the same time there are limits that we believe not being exactly placed either in the sphere of the actions of child and adolescent mental health workers or in the psychosocial mode adopted as a premise of the actions (Delfini et al., 2009; Taño \& Matsukura, 2014; Fernandes \& Matsukura, 2016).

Regarding the main limits, we understand that they are linked to a need for expanding and enhancing policies and guarantees of execution, considering, in fact, the complexity and uniqueness of childhood and adolescence (Taño \& Matsukura, 2014; Fernandes \& Matsukura, 2016).

Taking the network implied care, as explained in the psychosocial mode and in the current policies and, returning to the issue of intense psychic suffering, we ask how to respond to less intense psychic suffering in an intra- and intersectoral network that is still being constituted?

Thus, we consider that defending the network implied care, although clearly legitimate, requires, for its feasibility, the extension of this premise to policies, actions and resources, both for the health sector itself (in specialized care, Primary Care and emergency network) as well as for other sectors that also need to commit in this direction. Without this advance, the enormous effort and commitment recognized in the field generate actions that, without support - legal, financial, human resources, technical and others - are not able to achieve.

By assuming this understanding, it is possible to partially justify why implementing a care network for childhood and adolescence is still fragile, since there has never been 
a sufficiently structured care model for this population that sustains a network care proposal.

This reflection is evident in the literature, such as the weakness regarding the care offered that goes through from the insufficient number of equipment in the territory, the quality of care, the understanding of the network logic operation and, mainly, a tendency to overvaluate and overload CAPSij as the only devices capable of responding to the demands of this population, since Primary Care teams still do not recognize they must be co-responsible for this demand (Horta et al., 2013; Ronchi \& Avellar, 2010).

This weakness, rather than showing the limits in the theoretical-technical operationalization of Psychosocial Care, hurts some of its substantial principles that have not yet been sufficiently invested, in part, by the persistent chronic condition of SUS underfunding. That is, the lack of resources and the historical relationship that health in general establishes with mental health leads municipalities to mainly allocate the care of this population segment to a single device - such as CAPSij, for example - which puts in risk support pillars of a network health model and at the same time the pillars of Psychosocial Care, such as those pointed out by Yasui (2010) (intersectoriality, interdisciplinarity, participation and implication of the subject in care, as well as horizontal organization of the care devices), evoking the established asylum-type model that, so far, we try to overcome.

Resuming the issue of CAPSij-focused care, results of studies have identified CAPSij as the main care device, often as the only possibility to respond to the demands implied in the complexity of suffering at this stage of life, whether from the health field, whether from education or families (Hoffmann et al., 2008; Delfini et al., 2009; Falavina \& Cerqueira, 2008; Fernandes \& Matsukura, 2016).

The results of the recent study by Silva et al. (2018), which aimed to identify how Psychosocial Care has occurred with adolescents in a municipality in the state of São Paulo, pointed out that CAPSij is the network device that acts as a gateway of mental health demand of adolescents in the municipality studied, thus having the challenge and a solitary role in the definition of the cases that will be assisted for CAPSij. In addition, the team has faced difficulties in enabling RAPS in the municipality and, despite thinking about intersectoral actions and trying to standardize Primary Care, professionals of this level of care affirm adolescents have difficulties in accessing this device and there are constant referrals.

The results of the aforementioned studies show the network functions, especially with regard to the figure and function of CAPSij, contrary to what is recommended by RAPS in the field of Psychosocial Care and that, as already mentioned, this occurs due to the difficulty of developing network actions with Primary Care or the and Rede de Urgência e Emergência (RUE), due to the absence of broader policies and mechanisms to ensure support for these actions (Silva et al., 2018; Hoffmann et al., 2008; Falavina \& Cerqueira, 2008).

In this sense, although CAPS (as the main instruments in the initial process of mental health policy implementation) should be conceived as a strategy of change in care that functions primarily through the organization of a large network of mental health care (Yasui, 2010), what we see in these devices, in a broad and persistent way, 
is the maintenance of a practice, still in line with an outpatient logic (Yasui \& CostaRosa, 2008).

Those practices, which in most cases lead to the production of processes of care individualization, isolation of teams/professionals with barriers to network care, low satisfaction of family members, low clinical resolution and a low potential for social transformation, tend to be potentiated with the increasing process of at least 3 interconnected phenomena: 1) the Process of childhood medicalization (Kamers, 2013); 2) the practices of life psychiatrization (Martins, 2009); and 3) the increasing interference of Neoliberalism in the construction of health policies (Borlini, 2010).

With regard to the latter, we m especially to the expansion of the privatization project and its effects of care models changes derived from the counter-reform of the State, especially in health policy.

According to Dagnino et al. (2006), three major corporate corporate-political projects are in dispute: (a) the authoritarian project (generally linked to states of exception or military regimes); (b) the neoliberal project; and (c) the democraticparticipatory project, the latter being clearly the project that has greater theoretical-practical convergence with the principles and guidelines of SUS, as a universal system that includes social control and democratic and participatory management as the core axes of its organization. The neoliberal project, on the other hand, has a broad interest in economic adjustment and market expansion, even through the exclusion of social participation and its submission to the interests of the medical-industrial complex.

The analysis of these three phenomena would yield, each of them, a new exclusive essay, however, based on studies already conducted on these processes, we point out that a common way to overcome them would be the increasing and longitudinal promotion of network actions (sectoral and intersectoral dimensions) in its economic, political and sociocultural dimensions.

For Yasui (2010), CAPS should be the means, the way and not the end. "It is the possibility of tessitura, of the plot, of care that is not performed in only one place, but is woven into a wide network of alliances that includes different social segments, different services, different actors and caregivers" (Yasui, 2010, p.115).

We point out that the current challenge is precisely to think strategies to activate CAPS, specifically CAPSij, potential for establishing bonds and partnerships with other devices and professionals to enable the tessitura of a network care. This certainly calls for professionals not only willingness and involvement, but also technical and even strategic qualification to design and build a children and adolescents mental health network model.

It is important to emphasize that CAPS, as care organizers, together with Primary Care, within $R A P S$, need to be recognized as such by professionals, but, more than that, these professionals need to be able to dedicate themselves to also create action strategies for the service to meet this goal.

We understand that from this transformation it is possible to envision a model of assistance, as well as a network functioning dynamic, so that the support pillars of this transformation, such as the exercise of citizenship rights and the social inclusion, can really be experienced by the assisted population. It is noteworthy that the exercise of 
citizenship rights and social inclusion of children, adolescents and their families pointed out here, refer to, for example:

- The possibility of entry and permanence of this population in school, as well as access to didactic-pedagogical strategies that meet their real needs and educational demands;

- Access to leisure activities and different living spaces in the territory, since studies indicate that this population opportunities of recreation are mostly the ones proposed by CAPSij, such as going to the cinema, the park etc. (Fernandes \& Matsukura, 2016).

- The possibility of social participation in different instances, assuming roles of social representation/action to foster the visibility of this population, but also the development of their autonomy and appropriation of themselves and their desires as a driving force to be in the world.

- The guarantee of reception and techno-care support to parents/guardians and family members.

Given the theoretical-practical impasses that demand advances, but mainly due to the various practical transformations and theoretical innovations that have been included and exercised by the Mental Health Policy, it is possible to talk about a Estratégia Atenção Psicossocial Psychosocial (EAPS) similar to the Estratégia da Saúde da Família (Yasui \& Costa-Rosa, 2008). Thus, Costa-Rosa \& Yasui (2009, p. 125) conceptualize EAPS as

[...] a logic capable of transcending Centros de Atenção Psicossocial (CAPS) as isolated devices (such as organizers of Atenção no Território) and that seeks to place them radically in the guidelines and principles of the Sistema Único de Saúde (SUS). EAPS guides Psychosocial Care in territoriality; completeness; principle of popular and workers' participation in the planning, management and control of health devices and actions; finally, EAPS should be based on the new definition of health created from the VIII Conferência Nacional de Saúde of 1986. Health as a variable-effect of the processes of social production of everyday life in a territory; far away, therefore from the scope of Assistance actions, no less alienated than they may be.

It is important to emphasize that EAPS, to the extent that it operates and implements the principle of integrality in the construction of care and assistance through the matrix of Primary Care and, together with the Estratégia de Saude da Familia, has the potential to enable the production of new meanings to the way CAPS work, which currently have based their practices in the outpatient way (Yasui \& Costa-Rosa, 2008).

We verified, therefore, that the implementation and operationalization of Psychosocial Care in its different dimensions, as well as EAPS', requires collective investments, innovative practices and, mainly, the involvement and persistence of care agents. On the last, Yasui \& Costa-Rosa (2008) consider that they, as a team, prove to 
be a support base, a major instrument of intervention and innovation in the production of care in the context of Psychosocial Care.

We question whether there is, in fact, Psychosocial Care for children and adolescents within SUS that responds to the different demands and singularities of the subjects and a real expansion of contributions both in the health area and others.

Furthermore, it is worth discussing that there is no production of health without production of mental health and citizenship. Therefore, it is necessary to take into account that, when proposing health care, the biological, psychic and social dimensions of individuals should be considered (Brasil, 2014a). In this direction, there is a fundamental component of practice in the field of general health care that concerns the production of subjectivity by the subjects, however, the Ministry of Health recognizes that the incorporation of this dimension by professionals is still a challenge (Costa-Rosa $\&$ Yasui, 2009) and, in addition, it is a gap in the articulation and implementation of public policies in general (Silva et al., 2018). According to Yasui \& Costa-Rosa (2008), professionals often do not learn, in their training process, ways to manage the impasses in subjectivity and suffering presented by the subjects who seek mental health services within SUS, impasses often triggered by everyday life processes.

We emphasize that in the field of mental health, the ethics descending from Psychosocial Care determines that care professionals operate as intercessors, enabling the subject to position and be protagonist in the health production path, allowing the development and access to subjectivities (Costa-Rosa, 2013). Due to the difficulty of incorporating this dimension into care practices, the Politica Nacional de Humanização of the Ministry of Health guides the relevance of subjectivity inclusion in care practices, emphasizing the importance of valuing the different actors involved in care (people in distress, professionals, managers); to stimulate empowerment and autonomy of such actors; to increase the level of co-responsibility in health production processes and subjects, as well as to identify social, collective and subjective needs in the health field (Costa-Rosa \& Yasui, 2009).

We verified, therefore, that the inclusion of the existence subjectivity extends beyond the field of mental health and health, although in this field it has a differentiated shape (Costa-Rosa \& Yasui, 2009). For Costa-Rosa (2013), the Psychosocial Paradigm carries technical and ethically the indissociability between subjectivity and psychic health.

We argue that assuming the subjective dimension of existence and life processes of the subjects, as well as the one arising from the encounters produced by the practice of care in the field of mental health, proves to be a fundamental component in the individual and collective construction of life paths, singular trajectories and possibility of producing meaning in what one is and in what one may want to be, despite the different and distinct experiences of suffering.

In the dimension of health as the production of a community of subjects responsible for caring for oneself and the other, it is essential to guarantee the right to speak and act. There is no possible accountability without ensuring listening to the responsible subject who acts in the world, and it is no different with children and adolescents. When they talk about and identify themselves with their own stories, children and adolescents see 
possibilities to find new meanings and new forms of insertion in the society and family (Brasil, 2014a). It is clear the importance and role of public managers and professionals from different sectors in enabling such children, adolescents and family members access to those experiences. In this sense,

It is necessary to recognize, and not forget, that we are actors of a social practice, which have the potential, through the encounters we lead in the daily life of our praxis, to produce new processes of subjectivation, to produce more autonomous ways of living and make a difference (Yasui \& Costa-Rosa, 2008, p. 35).

\section{Final Considerations}

In this essay we seek to reflect on how the field of Psychosocial Care for children and adolescents in psychological distress has been constituted in Brazil, based on the theoretical contribution of Psychosocial Care, with history-policy contextualization of child and adolescent mental health care as its guiding thread.

In order to understand this path and reflexively elucidate the current scenario, we follow a path in which the main limits, weaknesses and challenges to overcome in this field are evidenced. These challenges are revealed, among others, in the dichotomy between what has been proposed in a theoretical-political way, even if it is still under construction, and how this has, in fact, been consolidated in practice.

Thus, based on the parameters of the psychosocial paradigm, which concern the understanding of the health-disease-intervention trinomial; forms of intrainstitutional relations and, consequently, the ways of managing powers; to the different possibilities of exchange between subject and assistance equipment and the political and sociocultural purposes arising from the practice produced, and the subjectivity of the subject, it was possible to obtain elements to discuss and advance in the debates regarding the care offer (network of care devices, tendency to "Capsization" or Encapsulation) and structure (guiding principles and of SUS and Psychosocial Care of children and adolescents guidelines).

We hope that this essay can contribute to the current discussion and to advance, through theoretical-practical elements, for the guarantee and effectiveness of care, as well as the rights to this population, respecting the existing singularities and complexity.

\section{References}

Amarante, P. (1995). Novos sujeitos, novos direitos: o debate em torno da reforma psiquiátrica. Cadernos de Saúde Pública, 11(3), 491-494.

Amstalden, A. L. F., Hoffman, M. C. C. L., \& Monteiro, T. P. M. (2010). A política de saúde mental infanto-juvenil: seus percursos e desafios. In E. L. Ribeiro \& O. Y. Tanaka (Orgs.), Atenção em saúde mental para crianças e adolescentes no SUS (pp. 33-45). São Paulo: HUCITEC.

Beltrame, M. M., \& Boarini, M. L. (2013). Saúde mental e infância: reflexões sobre a demanda escolar de um CAPSi. Psicol. Cienc. Prof., 33(2), 336-349. 
Borlini, L. M. (2010). Há pedras no meio do caminho do SUS - os impactos do neoliberalismo na saúde do Brasil. Textos \& Contextos, 9(2), 321-333.

Brasil. (2005). Caminhos para uma politica de saúde mental infanto- juvenil. Brasília: Ministério da Saúde.

Brasil. (2011, 23 de dezembro). Portaria MS/GM no 3.088, de 23 de dezembro de 2011. Institui a Rede de Atenção Psicossocial para pessoas com sofrimento ou transtorno mental e com necessidades decorrentes do uso de crack, álcool e outras drogas no âmbito do Sistema Único de Saúde. Diário Oficial [da] República Federativa do Brasil, Brasília, seção 1, p. 59.

Brasil. (2012). Portal da Saúde. Brasília: CAPS. Recuperado em 1 de março de 2012, de http://portal.saude.gov.br/portal/saude/visualizar_texto.cfm?idtxt=29797\&janela

Brasil. (2014a). Fórum Nacional de Saúde Mental Infantojuvenil: recomendaçôes: de 2005 a 2012. Brasília: Ministério da Saúde.

Brasil. (2014b). Atenção psicossocial a crianças e adolescentes no SUS: tecendo redes para garantir direitos. Brasília: Ministério da Saúde.

Brasil. (2017, 21 de dezembro). Portaria no 3.588, de 21 de dezembro de 2017. Altera as Portarias de Consolidaçáo no 3 e no 6 , de 28 de setembro de 2017, para dispor sobre a Rede de Atenção Psicossocial, e dá outras providências. Diário Oficial [da] República Federativa do Brasil, Brasília.

Costa-Rosa, A. (2000). O modo psicossocial: um paradigma das práticas substitutivas ao modo asilar. In P. Amarante (Org.), Ensaios: subjetividade, saúde mental, sociedade (pp. 141-168). Rio de Janeiro: Fiocruz.

Costa-Rosa, A. (2013). Atenção psicossocial além da Reforma Psiquiátrica: contribuiçôes a uma clínica critica dos processos de subjetivação na saúde coletiva. São Paulo: Unesp.

Costa-Rosa, A., \& Yasui, S. (2009). Algumas notas para pensar a psiquiatria psicossocial. In I. V. M. Rabelo, R. C. Tavares \& Y. R. A. Faria (Orgs.), Olhares-experiências de CAPS: Centro de Atenção Psicossocial (pp. 126-137). Goiânia: Kelps.

Costa-Rosa, A., Luzio, C. A., \& Yasui, S. (2003). Atenção psicossocial: rumo a um novo paradigma na saúde mental coletiva. In P. Amarante. Archivos de saúde mental e atenção psicossocial (pp. 13-44). Rio de Janeiro: Nau.

Couto, M. C. V. (2001). Novos desafios à reforma psiquiátrica brasileira: necessidade da construção de uma política pública de saúde mental para crianças e adolescentes. In Brasil. Conselho Nacional de Saúde (Orgs.), Conferência Nacional de Saúde Mental: cuidar sim, excluir não (pp. 121-130). Brasília: Ministério da Saúde.

Couto, M. C. V., \& Delgado, P. G. G. (2015). Crianças e adolescentes na agenda política da saúde mental brasileira: inclusão tardia, desafios atuais. Psicologia Clínica, 27(1), 17-40.

Couto, M. C. V., Duarte, C. S., \& Delgado, P. G. G. (2008). A saúde mental infantil na Saúde Pública brasileira: situação atual e desafios. Revista Brasileira de Psiquiatria, 30(4), 384-389.

Cunha, C., \& Boarini, M. L. (2001). O Lugar da Criança e do Adolescente na Reforma Psiquiátrica. Revista Psicologia e Saúde, 3(1), 68-76.

Dagnino, E., Oliveira, A. J., \& Panfichi, A. (2006). Para uma outra leitura da disputa pela construção democrática na América Latina. In E. Dagnino, A. J. Olvera \& A. Panfichi (Orgs.), A disputa pela construção democrática na América Latina (pp. 13-91). São Paulo: Paz e Terra; Campinas: UNICAMP.

Delfini, P. S. S., Dombi-Barbosa, C., Fonseca, C. F. L., Tavares, C. M., \& Reis, A. O. A. (2009). Perfil dos usuários de um Centro de Atenção Psicossocial infantojuvenil da grande São Paulo, Brasil. Revista Brasileira de Crescimento e Desenvolvimento Humano, 19(2), 226-236. 
Falavina, O. P., \& Cerqueira, M. B. (2008). Saúde Mental Infanto-Juvenil: usuários e suas trajetórias de acesso aos serviços de saúde. Revista Espaço para a Saúde, 10(1), 34-46.

Fernandes, A. D. S. A., \& Matsukura, T. S. (2015). Adolescentes no CAPSi. Revista de Terapia Ocupacional da Universidade de São Paulo, 26(2), 216-224.

Fernandes, A. D. S. A., \& Matsukura, T. S. (2016). Adolescentes inseridos em um CAPSi: alcances e limites deste dispositivo na saúde mental infantojuvenil. Temas em Psicologia, 24(3), 977-990.

Hoffmann, M. C. C. L., Santos, D. N., \& Mota, E. L. A. (2008). Caracterização dos usuários e dos serviços prestados por Centros de Atenção Psicossocial Infanto-Juvenil. Cadernos de Saúde Pública, 24(3), 633-642.

Horta, R. L., Esswein, G. C., \& Horta, C. L. (2013). Percepção de profissionais de saúde de CAPS I quanto a demandas relativas ao consumo de crack. Ciência \& Saúde Coletiva, 18(4), 1099-1108.

Kamers, M. (2013). A fabricação da loucura na infância: psiquiatrização do discurso e medicalização da criança. Estilos da Clínica, 18(1), 153-165.

Martins, A. L. (2009). A psiquiatrização da vida na sociedade de controle. In S. Carvalho, M. E. Barros \& S. Ferigato (Orgs.), Conexóes saúde coletiva e políticas de subjetividade (pp. 119140). São Paulo: Hucitec.

Reis, A. O. A., Delfini, P. S. S., Dambi-Barbosa, C., \& Oliveira, M. F. A. P. B. (2010). Crianças e adolescentes em sofrimento psíquico atendidos nos centros de atençáo psicossocial infantojuvenis. In E. L. Ribeiro \& O. Y. Tanaka (Orgs.), Atenção em saúde mental para crianças e adolescentes no SUS (pp. 186-210). Sáo Paulo: Hucitec.

Ribeiro, P. R. M. (2006). História da saúde mental infantil: a criança brasileira da Colônia à República Velha. Psicologia em Estudo, 11(1), 29-38.

Ronchi, J. P., \& Avellar, L. Z. (2010). Saúde mental da criança e do adolescente: a experiência do Capsi da cidade de Vitória-ES. Psicologia: Teoria e Prática, 12(1), 71-84.

Schechtman, A., \& Alves, D. S. (2014). A organização da política de saúde mental. In M. A. S. Jorge, M. C. Carvalho \& P. R. F. Silva. Politicas e cuidado em saúde mental: contribuiçōes para a prática profissional (pp.41-58). Rio de janeiro: FIOCRUZ.

Silva, J. F., Cid, M. F. B., \& Matsukura, T. S. (2018). Atenção psicossocial de adolescentes: a percepção de profissionais de um CAPSij. Cadernos Brasileiros de Terapia Ocupacional, 26(2), 329-343.

Taño, B. L., \& Matsukura, T. S. (2014). Os centros de atenção psicossocial infantojuvenis: características organizacionais e oferta de cuidados. Revista de Terapia Ocupacional da Universidade de São Paulo, 25(3), 208-216.

Taño, B. L., \& Matsukura, T. S. (2015). Saúde mental infantojuvenil e desafios do campo: reflexóes a partir do percurso histórico. Cadernos de Terapia Ocupacional da UFSCar, 23(2), 439-447.

Yasui, S. (2009). A atenção psicossocial e os desafios do contemporâneo: um outro mundo é possível. Cadernos Brasileiros de Saúde Mental, 1(1), 1-9.

Yasui, S. (2010). Rupturas e Encontros: desafios da Reforma Psiquiátrica brasileira. Rio de Janeiro: Fiocruz.

Yasui, S., \& Costa-Rosa, A. (2008). A estratégia atenção psicossocial: desafio na prática dos novos dispositivos de saúde mental. Saúde em Debate, 32(78/80), 27-37. 


\section{Author's Contributions}

Amanda Dourado Souza Aksahosi Fernandes and Giovana Garcia Morato participated in the whole process of construction and elaboration of the text, from its conception, organization of sources and critical analysis, writing and review. Thelma Simóes Matsukura, Sabrina Helena Ferigato and Isabela Aparecida de Oliveira Lussi participated in the paper writing and review. All authors approved the final version of the article.

\section{Corresponding author}

Amanda Dourado Souza Akahosi Fernandes

e-mail: amanda.d.fernandes@hotmail.com 